\title{
Simvastatin improves the healing of infected skin wounds of rats ${ }^{1}$
}

\author{
A sinvastatina melhora a cicatrização de feridas infectadas da pele de ratos
}

\begin{abstract}
Amália Cínthia Meneses do Rego² Irami Araújo Filho ${ }^{3}$, Bolívar P G L Damasceno ${ }^{3}$, Eryvaldo Sócrates Tabosa Egito ${ }^{4}$, Ivanaldo Amâncio da Silveira ${ }^{5}$, José Brandão-Neto ${ }^{6}$, Aldo Cunha Medeiros ${ }^{7}$.
\end{abstract}

1. Department of Surgery, School of Medicine, Federal University of Rio Grande Norte (UFRN)- Natal, Brazil.

2. Graduate student, Scientific Initiation Program, UFRN, Brazil.

3. PhD Fellow of Postgraduate Program in Health Sciences, UFRN, Brazil.

4. PhD, Adjunct Professor, Department of Pharmacy, UFRN, Brazil.

5. Adjunct Professor, Department of Clinical Analysis, UFRN, Brazil.

6. Full Professor, Postgraduate Program in Health Sciences, UFRN, Brazil.

7. Full Professor, Department of Surgery, UFRN, Brazil.

\begin{abstract}
Purpose: This study explores the potential of the simvastatin to ameliorate inflammation and infection in open infected skin wounds of rats. Methods: Fourteen Wistar rats weighing $285 \pm 12 \mathrm{~g}$ were used. The study was done in a group whose open infected skin wounds were treated with topical application of sinvastatina microemulsion (SIM, $\mathrm{n}=7$ ) and a second group with wounds treated with saline $0.9 \%$ (SAL, n=7). A bacteriological exam of the wounds fluid for gram positive and gram negative bacteria, the tecidual expression of TNFá and IL-1â by imunohistochemical technique, and histological analysis by HE stain were performed. Results: The expression of TNFa could be clearly demonstrated in lower degree in skin wounds treated with simvastatin $\left(668.6 \pm 74.7 \mathrm{im}^{2}\right)$ than in saline $\left(2120.0 \pm 327.1 \mathrm{ìm}^{2}\right)$. In comparison, wound tissue from SIM group displayed leukocyte infiltration significantly lower than that observed in SAL group $(\mathrm{p}<0.05)$. Culture results of the samples taken from wound fluid on fourth post treatment day revealed wound infection in only one rat of group simvastatin (SIM), where Proteus mirabilis, Escherchia coli and Enterobacter sp were isolated. In the rats whose wounds were treated with saline (SAL), polymicrobial infection with more than 100,000 CFU/g was detected in all the wounds. Conclusion: In addition to its antiinflammatory properties, the protective effects of simvastatin in infected open skin wounds is able to reduce infection and probably has antibacterial action. The potential to treat these wounds with statins to ameliorate inflammation and infection is promising.
\end{abstract}

Key words: Statin. Inflammation. Wound Healing. Wistar rat. Skin. Cytokine.

\begin{abstract}
RESUMO:
Objetivo: O presente estudo avaliou o potencial da sinvastatina para atenuar a inflamação e a infecção em feridas abertas infectadas de pele de ratos. Métodos: Foram utilizados 14 ratos Wistar pesando $285 \pm 12 \mathrm{~g}$. O estudo foi realizado com um grupo de animais cujas feridas abertas infectadas foram tratadas com aplicação tópica de sinvastatina microemulsão (SIM, $\mathrm{n}=7$ ) e um segundo grupo com feridas tratadas com solução salina 0,9\% (SAL n=7). Foi realizado exame bacteriológico do fluido das feridas para detecção de bactérias gram positivas e negativas, a expressão tecidual de TNFá e IL-1â por imunohistoquímica e análise histológica pela coloração H-E. Resultados: A expressão do TNFa pode ser claramente demonstrada em menor grau nas feridas de pele tratadas com sinvastatina (668.6 \pm 74.7 ìm²) do que no grupo salina (2120.0 \pm 327.1 ìm²). Em comparação, os tecidos das feridas do grupo SIM mostrou infiltração leucocitária significantemente menor do que a observada no grupo SAL $(\mathrm{p}<0,05)$. O resultado das culturas realizadas no fluido das feridas no $4^{\circ}$ dia de tratamento revelou infecção em apenas um rato do grupo sinvastatina (SIM), onde Proteus mirabilis, Escherchia coli e Enterobacter sp foram isolados. Nos ratos cujas feridas foram tratadas com solução salina (SAL), infecção polimicrobiana com mais de 100,000 UFC/g foi detectada em todas as feridas. Conclusão: Além de suas propriedades antiinflamatórias, o efeito protetor da sinvastatina em feridas abertas e infectadas de pele é capaz de reduzir a infecção e provavelmente tem ação antibacteriana. O potencial da droga para atenuar inflamação e infecção de feridas é promissor.
\end{abstract}

Descritores: Estatinas. Inflamação. Cicatrização de Feridas. Rato Wistar. Pele. Citocinas. 


\section{Introduction}

The healing of open skin wounds involves the epithelium and underlying stroma. Processes such as angiogenesis, activation, migration, and proliferation of fibroblasts, myofibroblasts and endothelial cells; formation of granulation tissue; and wound contraction are needed to close these defects ${ }^{1,2}$. Some wounds are also frequently inflamed and, in general, stromal involvement and inflammation greatly increase the risk of subsequent complications ${ }^{3,4}$ The repair process begins immediately after injury by the release of various growth factors, cytokines, and low-molecular weight compounds. Disruption of blood vessels also leads to the formation of the blood clot, which is composed of cross-linked fibrin, and of extracellular matrix proteins such as fibronectin, tenascin, and thrombospondin ${ }^{5}$. Wound infection develops in $2 \%$ to $5 \%$ of patients undergoing surgical procedures each year in most hospitals worldwide and continues being considered one of the most important problems in surgical wards nowadays. It is one of the main factors that alter the physiologic evolution of the wound healing ${ }^{6,7}$ The bacteria inhibit the angiogenesis, secrete plasminogen activators, and proteolitic enzymes that may affect the extracelular matrix, blocking the wound contraction ${ }^{8}$ Several substances have been used to treat infected skin wounds, like honey, sugar, antibiotics, phytotherapics ${ }^{9,10,11,12,13}$ Statins are a class of compounds that competitively inhibit the enzyme 3-hydroxy-3-methylglutaryl coenzyme A (HMG-CoA) reductase, the first committed step in cholesterol biosynthesis. Increasingly, the pleiotropic properties of statins are being described. In endothelial cells, all of these effects seem to result from the inhibition of cholesterol's precursor mevalonic acid, which is critical to the isoprenylation of a diverse family of proteins ${ }^{14,15}$. Simvastatin, a HMG-CoA reductase inhibitor, have been shown to exhibit important immunomodulatory effects independent of lipid lowering ${ }^{16}$. These pleiotropic effects have been demonstrated to include anti-inflammatory actions ${ }^{17}$. improvement of endothelial and microvascular function, modulation of endothelial nitric oxide synthase $(\mathrm{eNOS})^{18}$, ischemia/reperfusion ${ }^{19}$ and sepsis ${ }^{20}$. However, statins have not been used to treat skin infected wounds. We thus approached the question of whether topical treatment with simvastatin might improve the healing of skin infected wounds in a rat model.

\section{Methods}

The experimental protocol was approved by the Research Ethics Committee (Animal Research Ethics Division) of the University Hospital-UFRN, Brazil. Animals were handled in accordance with the Guide for the Care and Use of Laboratory Animals, Brazilian College of Animal Experimentation.

\section{Animals}

Wistar rats (Rattus norvegicus albinus, Rodentia mammalia) weighing 282???g were used. They were housed in polypropilene cages and maintained under controlled temperature conditions on a $12 \mathrm{~h}$ light-dark cycle and allowed ad libitum access to commercially available rat chow (Labina, Purina $\left.{ }^{\circledR}\right)$ and water.

\section{Experimental design and procedures}

The animals were randomly separated in two groups of seven rats each. After 12 hours of fasting, the rats were anesthetized by intramuscular injection of $30 \mathrm{mg} / \mathrm{Kg}$ of ketamine and thiopental $20 \mathrm{mg} / \mathrm{Kg}$ intraperitoneal. After dorsal skin depilation and anti-sepsis with $1 \%$ povidona, the surgical procedures were performed under aseptic conditions. An open skin squared wound $\left(1 \mathrm{~cm}^{2}\right)$, was done in the dorsal skin of all the rats. Immediately after the surgical procedure, the wounds were contaminated with topical application of $0.5 \mathrm{~mL}$ of multibacterial solution prepared with $1 \mathrm{~g}$ of rats fresh feces and $10 \mathrm{~mL}$ of saline. In the following day, the infected wounds of the simvastatin group (SIM) $(n=7)$ were topically treated with $0.2 \mathrm{ml}$ of simvastatin microemulsion $(10 \mathrm{mg} / \mathrm{mL})$ once a day. The wounds of group saline (SAL) $(n=7)$ rats were treated with $0.2 \mathrm{ml}$ of saline solution daily. When the wounds were totally epithelialized, the healing time was recorded and the resection of the scar was performed under anesthesia. The healed tissues were used for histopathological study and immunohistochemical dosage of tumor necrosis factor- $\alpha$ (TNF- $\alpha)$ and interleukine-

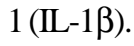

\section{Immunohistochemical staining of TNF- $\alpha$ and $I L-1 \beta$.}

Immunohistochemical staining for TNF- $\alpha$ and IL-1 $\beta$ was performed on tissue samples obtained from the healing skin. These samples were fixed in $4 \%$ paraformaldehyde, processed in routine technique, cut into $5 \mathrm{~mm}$-thick frozen sections, and dried at room temperature. Absolute methanol containing 3\% hydrogen peroxide was added to block endogenous peroxidase. After three washings with a phosphate-buffered solution (PBS) for 5 min each, these sections were treated with $1 \%$ polyoxyethylene-10-octylphenyl ether in PBS for 20 min at room temperature. After washing in the same way, these were reacted with $100 \mathrm{ml}$ of biotinylated anti-rat TNF- $\alpha$ monoclonal antibody (Pharmingen, San Diego, CA) or biotinylated anti-rat IL-1 $\beta$ monoclonal antibody (Pharmingen), diluted in $9 \mathrm{~mL}$ of PBS and $1 \mathrm{ml}$ of whole goat serum at room temperature in a moist chamber for 2 h. After washing, the preparations were incubated, with two drops each of avidin solution and biotinylated peroxidase solution in $4.5 \mathrm{ml}$ of PBS and $0.5 \mathrm{ml}$ of $5 \%$ skim milk for $2 \mathrm{~h}$ at $37^{\circ} \mathrm{C}$. After PBS rinsing, diaminobenzidine and nickel were applied for 8 min to 
achieve permanent color change. Six views were selected randomly for each section and observed under a light microscope (x100). The mean number of reactive cells in the six views was regarded as the data for each sample. Sequential images of microscopic sections were photographed within 72 hours after immunostaining, by a digital camera (Sony, Tokyo, Japan) mounted on a light microscope (Olympus B-50, Tokyo, Japan) at a magnification of 100x, and saved in jpg file format. Images were then analyzed in ImagePro-Plus software (Media Cybernetics, LP, USA). Briefly, the entire area colored by cytokines was marked, and the total marked area was calculated. The area stained by the antibody of interest was identified and calculated by using the software color algorithm. The integrated optical areas stained by antibodys were then recorded. The score index was calculated for each of the antibodies and it was averaged.

\section{Histopathology}

The biopsies of skin wounds were processed following the routine and stained with hematoxilin and eosin (HE) for histological analysis of the inflammatory reaction, using the optical microscope Olympus B-50, Japan, Tokyo. The quantification of cells, fibers and elements of the inflammatory reaction was performed by the Image Pro-Plus Média Cybernetics software, LP, USA.

\section{Bacteriological examination}

At the $4^{\text {th }}$ postoperative day, exsudato was collected from the wounds for microbiology and for quantitation of bacterial population. The materials were processed and cultured on selective MacConkey's agar, blood agar and salt manitol agar. The agar plates were incubated at $37^{\circ} \mathrm{C}$ and examined for growth after 24,48 and 72 hours. Any growth in the plates of bacteria of the same biotype as cultured in the wounds was considered positive and expressed as colony-forming units per gram of tissue (CFU/g). All procedures were performed under laminar air flux.

\section{Statistical analysis}

Data are presented as the mean \pm standard deviation. Results were analyzed with ANOVA and Student t test. Statistical significance was assumed at $\mathrm{p}<0.05$.

\section{Results}

\section{Tumor necrosis factor alpha (TNF $\alpha)$}

The expression of TNF $\alpha$ could be clearly demonstrated in lower degree in skin wounds treated with simvastatin $\left(668.6 \pm 74.7 \mathrm{ìm}^{2}\right)$ than in saline $(2120.0 \pm 327.1$ $\mathrm{ìm}^{2}$ ) treated wounds, as can be shown in figure 1 and table 1 . So, a distinct decrease of tissue reactivity occurred when the simvastatin microemulsion was applied to the infected wounds.

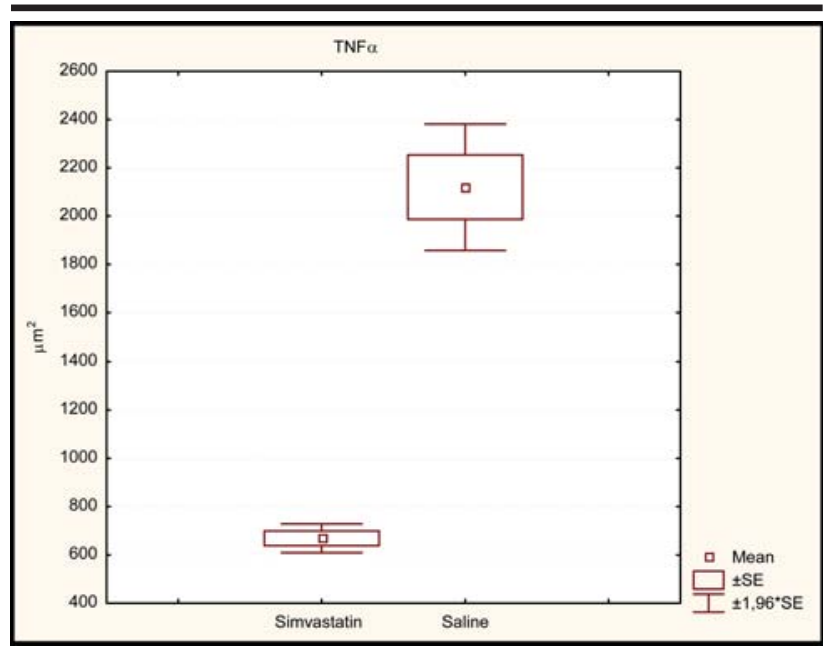

FIGURE 1 - Mean areas corresponding to the expression of TNF $\alpha$ Significant difference comparing the groups simvastatin and saline $(\mathrm{p}<0.05)$.

TABLE 1 - Mean and statistical analysis of optical density related to the expression of cytokines in tissues of skin infected wounds treated with simvastatin and saline ( $\mu \mathrm{m} 2)$.

\begin{tabular}{l|l|l|l}
\hline Cytokines & $\begin{array}{l}\text { Groups } \\
(\mathrm{SIM}) *\end{array}$ & $\begin{array}{l}\text { Saline } \\
(\mathrm{SAL}) *\end{array}$ & p-value \\
\hline $\mathrm{TNF} \alpha$ & $668.6 \pm 74.7$ & $2120.0 \pm 327.1$ & 0.00001 \\
$\mathrm{IL}-1 \beta$ & $467.6 \pm 55.2$ & $691.6 \pm 67.4$ & 0.00001 \\
\hline
\end{tabular}

* Mean \pm Standard deviation

1 - Difference statistically significant comparing the groups SIM/ SAL (Student $t$ test).

Image Pro-plus software Media Cybernetics was used.

\section{Interleukin-1b}

$I L-1 b$ expression was significantly more enhanced in the saline (SAL) group than in the Simvastatin (SIM) group after total epithelialization of the skin wounds. A clearly decreased immunohistochemical stainability could be noticed in the SIM group, whose data are expressed in figure 2 and table 1.

\section{Histopathology}

Contamination of skin wounds with multibacterial fecal solution caused intense inflammatory reaction in tissues of group SAL rats, with edema and marked leukocyte infiltration consistent with acute injury (Figure 3). In comparison, wound tissue from SIM group displayed leukocyte infiltration significantly lower than that observed in SAL group. $(\mathrm{p}<0.05)$. These pathologic changes were reduced by the administration of simvastatin topically in the infected wounds (Table 2) The histological slides (figures 3 and 4) suggest differences in neutrophil accumulation between the SAL and SIM groups. 
TABLE 2 - Histological grading based in the optical density related related to the inflammatory reaction in tissues of skin infected wounds treated with simvastatin and saline $\left(\mu m^{2}\right)$

\begin{tabular}{l|l|l|l}
\hline Inflammation & $\begin{array}{l}\text { Simvastatin } \\
(\mathrm{SIM})^{*}\end{array}$ & $\begin{array}{l}\text { Saline } \\
(\mathrm{SAL})^{*}\end{array}$ & p-value \\
\hline $\begin{array}{l}\text { Inflammatory } \\
\text { reaction }\end{array}$ & $844.7 \pm 65.2$ & $3416.1 \pm 233.4$ & 0.00001 \\
\hline
\end{tabular}

* Mean \pm Standard deviation

1 - Difference statistically significant comparing the groups SIM/

SAL (Student t test).

Image Pro-plus software Media Cybernetics was used.

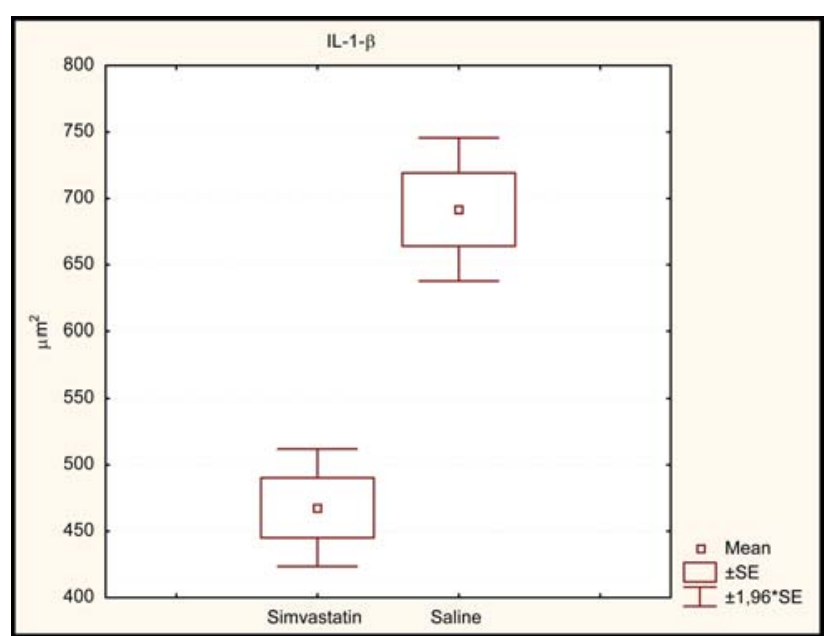

FIGURE 2 - Mean areas corresponding to the expression of IL-1 $\beta$ Significant difference comparing the groups simvastatin and saline $(\mathrm{p}<0.05)$.

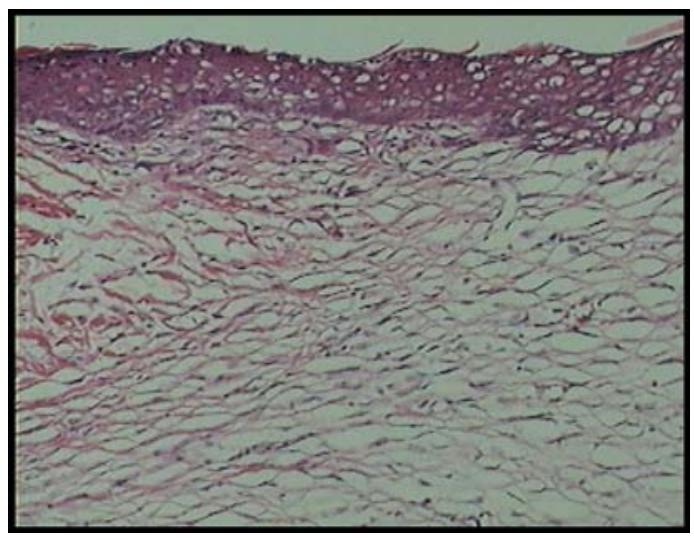

FIGURE 3 - Histological section of wound tissue taken from a SAL group rat, demonstrating significant neutrophil infiltration, giant cells and folicules. HE, 100x.

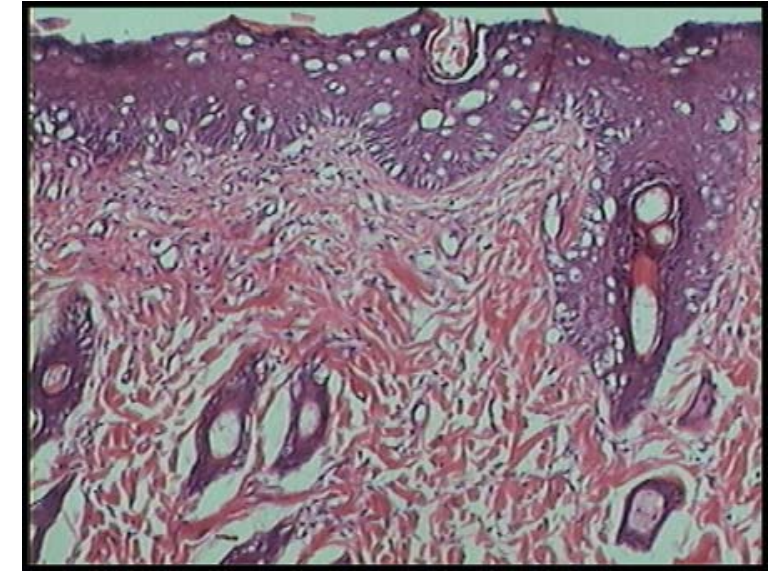

FIGURE 4 - Histological section of wound tissue taken from SIM group rat, demonstrating low neutrophil infiltration and good epithelial regeneration. HE, 100x.

\section{Bacteriological examination}

Culture results of the samples taken from wound fluid on fourth post treatment day revealed wound infection in only the rat number 4 of group simvastatin (SIM), where Proteus mirabilis, Escherchia coli and Enterobacter $s p$ were isolated. In the rats whose wounds were treated with saline (SAL), polymicrobial infection with more than 100,000 CFU/g was detected in all the wounds (Table 3 ). The most frequently isolated microorganisms can be observed in table 3 . 
TABLE 3 - Detection of bacteria in the wound fluid of animals in groups treated with simvastatin (SIM) and treated with saline (SAL).

\begin{tabular}{|c|c|c|c|c|}
\hline $\begin{array}{l}\text { Rat } \\
\text { number }\end{array}$ & $\begin{array}{l}\text { SIM Group/ } \\
\text { bacteria }\end{array}$ & $\mathrm{CFU} / \mathrm{g}$ & SAL Group/bacteria & CFU/g \\
\hline 1 & NBG & 0 & $\begin{array}{l}\text { Klebsiella sp; Proteus } \\
\text { Mirabilis; Proteus vulgaris; } \\
\text { Staphylococcus coagulase } \\
\text { negative }\end{array}$ & $>100,000$ \\
\hline 2 & NBG & 0 & $\begin{array}{l}\text { Proteus mirabilis; Escherichia } \\
\text { coli; Staphylococcus } \\
\text { coagulase negative }\end{array}$ & 90,000 \\
\hline 3 & NBG & 0 & $\begin{array}{l}\text { Proteus mirabilis; Escherichia } \\
\text { coli; Staphylococcus } \\
\text { coagulase negative }\end{array}$ & $>100,000$ \\
\hline 4 & $\begin{array}{l}\text { Proteus mirabilis; } \\
\text { Escherichia coli; } \\
\text { Enterobacter sp }\end{array}$ & 50,000 & $\begin{array}{l}\text { Klebsiella sp; Proteus } \\
\text { mirabilis }\end{array}$ & $>100,000$ \\
\hline 5 & NBG & 0 & $\begin{array}{l}\text { Escherichia coli; Enterobacter } \\
\text { sp; Proteus mirabilis }\end{array}$ & $>100,000$ \\
\hline 6 & NBG & 0 & $\begin{array}{l}\text { Proteus mirabilis; Escherichia } \\
\text { coli }\end{array}$ & $>100,000$ \\
\hline
\end{tabular}

NBG, No bacterial growth; CFU/g, Colony forming unit per gram.

\section{Discussion}

Cutaneous wound healing is a complex process involving blood clotting, inflammation, new tissue formation, and finally tissue remodeling ${ }^{21 .}$ It is well described at the histological level and many experimental and clinical studies have demonstrated varied, but in most cases beneficial, effects of exogenous substances ${ }^{11,12,13}$ on the healing process. However, the roles played by these exogenous treatments have remained largely unclear. HMG-CoA reductase inhibitors (statins) are used clinically for lowering hypercholesterolemia because of their inhibitory effect on hepatic biosynthesis of cholesterol at the mevalonate step ${ }^{22}$. These statins such as simvastatin have been shown to exhibit important immunomodulatory effects independent of lipid lowering $^{23}$ These pleiotropic effects have been demonstrated to include anti-inflammatory actions ${ }^{24}$. The present study is one of the first to demonstrate that HMG-CoA reductase inhibitors significantly improve healing of infected skin wounds in an experimental model in rats. The improvement in inflammatory reaction and in cytokines expression corroborates some results in the literature that clearly demonstrate that simvastatin is a potent and effective endothelium-protective agent that reduces leukocyte-endothelial cell interactions independently of its well-known lipid-lowering effects. This effect has been found to be at least partially mediated via downregulation of P-selectin expression on the microvascular endothelium. Thus, HMG-CoA reductase inhibitors like simvastatin have important anti- inflammatory effects besides their well-known lipidlowering action ${ }^{25,26}$. In the present study we demonstrated that the topical application of simvastatin microemulsion attenuated the inflammatory reaction in wound healing of infected tissues, but to date the mechanism is not clear. Prueffer et $\mathrm{al}^{27}$.demonstrated a protective effect of simvastatin under conditions of acute inflammation induced by an exotoxin within the microcirculation. In particular, they provide strong evidence that simvastatin is able to attenuate enhanced leukocyte-endothelium interaction after $S$ aureus toxin administration. Pore-forming $S$ aureus toxin is known to provoke inflammatory acctivation ${ }^{28,29,30}$. These evidences may explain hour results with the topical use of simvastatin in the healing of infected wounds. Statins affect the production of many acute phase reactants, including CRP, which is produced in the liver under stimulation by cytokines (IL-1 and IL-6). In nonatherosclerotic huCRP transgenic mice, statins decreased basal and IL-1b-induced plasma huCRP levels independently of cholesterol lowering and of an effect on IL-6 production ${ }^{31}$. In fact, in this work simvastatin was able to induce a marked decrease in TNF $\alpha$ anf IL-1 $\beta$ in healing tissues, as demonstrated by immunohystochemical analysis. A probable antibacterial effect was also observed, and the exact mechanism to explain this action is to be described. In an other study the pretreatment was found to decrease cytokinestimulated transcription factor activation and iNOS expression in the endothelium, stating that simvastatin affect cytokines with several ways $^{32}$. 


\section{Conclusion}

In addition to its antiinflammatory properties, the protective effects of simvastatin in infected open skin wounds is able to reduce infection and probably has antibacterial action. The potential to treat these wounds with statins to ameliorate inflammation and infection is promising.

\section{References}

1. Clark RAF. Wound repair. Overview and general considerations. In: The Molecular and Cellular Biology of Wound Repair (2nd ed.), edited by Clark RAF. New York: Plenum, 1996, p. 3-50.

2. Martin P. Wound healing-aiming for perfect skin regeneration. Science 276: 75-81, 1997 .

3. Redd MJ, Cooper L, Wood W, Stramer B, Martin P. Wound healing and infl ammation: embryos reveal the way to perfect repair. Philos Trans R Soc Lond B Biol Sci 2004; 359: 777-84.

4. Hinz B, Gabbiani G. Cell-matrix and cell-cell contacts of myofi broblasts: role in connective tissue remodeling. Thromb Haemost 2003; 90: 993-1002].

5. Clark RAF. Regulation of fibroplasia in cutaneous wound repair. Am J Med Sci. 1993; 306: 42-8.

6. Pishori T, Siddiqui AR, Ahmed M. Surgical wound infection surveillance in general surgery procedures at a teaching hospital in Pakistan. Am J Infect Control. 2003;31:396-1.

7. Narong MN, Thongpiyapoom S, Thaikul N, Jamulitrat S, Kasatpibal N. Surgical site infection in patients undergoing major operations in a university hospital: Using standardized infection ratio as a benchmarking tool. Am J Infect Control. 2003;31:274-9.

8. Perry AW, Sutkin HS, Gottlieb LD. Skin graft survival. The bacterial answear. Ann Plast Surg. 1989; 22:47983.10 .

9. Santos MFS, Czeczko NG, Nassif PAN, Ribas-Filho JM, Alencar BLF, Malafaia O, Ribas CAPM, TrautweinVM, Henriques GS, Maia JMA, Bittencourt RCA. Evaluation of the use of raw extract of Jatropha gossypiifolia $L$. in the healing process of skin wounds in rats. Acta Cir Bras. 2006;(supl.3):21:2-7.

10. Nunes Jr JAT, Ribas-Filho JM, Malafaia O, Czeczko NG, Inácio CM Negrão AW, Lucena PLH, Moreira H, Wagenfuhr Jr J, Cruz JJ. Evaluation of the hydroalcoholic Schinus terebinthifolius Raddi (Aroeira) extract in the healing process of the alba linea in rats. Acta Cir Bras. 2006; (supl.3)21:8-15.

11. Garros IC, Campos ACL, Tâmbara EM, Tenório SB, Torres OJM,; Agulham MA, Araújo ACF, Santis-Isolan PMB, Oliveira RM, Arruda ECM. Extract from Passiflora edulis on the healing of open wounds in rats: morphometric and histological study. Acta Cir Bras. 2006; (supl.3)21:55-65.

12. Martins NLP, Malafaia O, Ribas-Filho J M, Heibel M, Baldez RN, Vasconcelos PRL, Moreira H, Mazza M, Nassif PNA, Wallbach TZ. Healing process in cutaneous surgical wounds in rats under the influence of Orbignya phalerata aqueous extract. Acta Cir Bras. 2006; (supl.3)21:66-75.

13. Biondo-Simões MLP, Gomes ADZA, Poncio C, Torres LFB, Borsato KS. Influência da hipertensão arterial tratada com losartan na cicatrização de feridas cutâneas em ratos.Acta Cir Bras. 2006;21:144-50.

14. Goldstein JL, Brown MS. Regulation of the mevalonate pathway. Nature. 1990;343:425-30.

15. Corsini A, Bellosta S, Baetta R, Fumagalli R, Paoletti $\mathrm{R}$, Bernini F. New insights into the pharmacodynamic and pharmacokinetic properties of statins. Pharmacol Ther. 1999;84:413-28.

16. Kwak B, Mulhaupt F, Myit S. Statins as a newly recognized type of immunomodulator. Nat Med. 2000;6:1399-402.

17. Pruefer D, Makowski J, Schnell M. Simvastatin inhibits inflammatory properties of Staphylococcus aureus alpha toxin. Circulation. 2003;106:2104-2110.)

18. Laufs U, Liao JK. Post-transcriptional regulation of endothelial nitric oxide synthase mRNA stability by Rho GTPase. J Biol Chem. 1998;273:24266-71.,

19. Naidu BV, Woolley SM, Farivar AS, Thomas R, Fraga C, Mulligan MS. Simvastatin ameliorates injury in an experimental model of lung ischemia-reperfusion. $\mathrm{J}$ Thorac Cardiovasc Surg. 2003;126:482-9.

20. Merx MW, Liehn EA, Janssens U, Lütticken R, Schrader J, Hanrath P, Weber C. HMG-CoA reductase inhibitor simvastatin profoundly improves survival in a murine model of sepsis. Circulation. 2004;109:2560-5.

21. MARTIN P. Wound healing-aiming for perfect skin regeneration. Science. 1997; 276: 75-81.

22. Alberts AW. Discovery, biochemistry and biology of lovastatin. Am JCardiol. 1988;62:10-15.

23. Kwak B, Mulhaupt F, Myit S. Statins as a newly recognized type of immunomodulator. Nat Med. 2000;6:1399-402.

24. Pruefer D, Makowski J, Schnell M. Simvastatin inhibits inflammatory properties of Staphylococcus aureus alpha toxin. Circulation. 2003;106:2104-10.

25. Pruefer D, Scalia R, Lefer AM. Simvastatin inhibits leukocyte-endothelial cell interactions and protects against inflammatory processes in normocholesterolemic rats. Arterioscler Thromb Vasc Biol. 1999;19:2894-900.

26. Kimura M, Kurose I, Russell J, Granger DN. Effects of fluvastatin on leukocyte-endothelial cell adhesion in hypercholesterolemic rats. Arterioscler Thromb Vasc 
Biol. 1997;17:1521-1526.

27. Pruefer D, Makowski J, Schnell M, Buerke U, Dahm M, Oelert H, Sibelius U,Grandel U, Grimminger F, Seeger W, Meyer J, Darius H, Buerke M. Simvastatin Inhibits Inflammatory Properties of Staphylococcus aureus á-Toxin. Circulation. 2002;106:2104-2110.

28. Valeva A, Weisser A, Walker B, et al. Molecular architecture of a toxin pore: a 15-residue sequence lines the transmembrane channel of staphylococcal á- toxin. EMBO J. 1996;15:1857-64.

29. Sibelius U, Grandel U, Buerke M. Staphylococcal á toxin provokes coronary vasoconstriction and loss in myocardial contractility in perfused rat hearts: role of thromboxane generation. Circulation. 2000;101:78-85.
30. Buerke M, Sibelius U, Grandel U. Staphylococcus aureus á- toxin mediates polymorphonuclear leukocyte induced vasocontraction and endothelial dysfunction. Shock. 2002;17:30-5.

31. Kleemann R, Verschuren L, de Rooij BJ, Lindeman J, de Maat MM, Szalai AJ, Princen HM, Kooistra T. Evidence for anti-inflammatory activity of statins and PPARalpha activators in human C-reactive protein transgenic mice in vivo and in cultured human hepatocytes in vitro. Blood. 2004;103:4188-94.

32. Giusti-Paiva A, Martinez MR, Felix JV, da Rocha MJ, Carnio EC, Elias LL, Antunes-Rodrigues J (2004) Simvastatin decreases nitric oxide overproduction and reverts the impaired vascular responsiveness induced by endotoxic shock in rats. Shock. 21:271-5.
Correspondence:

Aldo Cunha Medeiros

Av. Miguel Alcides Araújo 1889

Natal, RN, Brazil
Source of funding: Conflict of interest: 